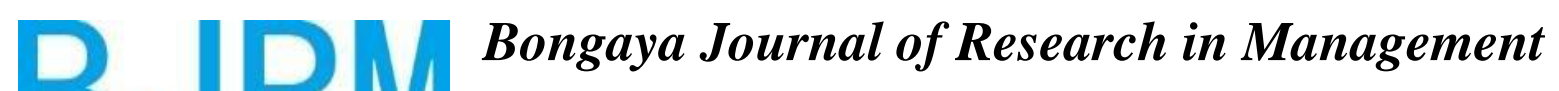

Volume 1 Nomor 2. Hal 18-24. e-ISSN: 2615-8868

Homepage: https://ojs.stiem-bongaya.ac.id/index.php/BJRM

\section{PENGARUH KEPUASAN INFORMASI TERHADAP KEPUASAN MEMILIH PERGURUAN TINGGI}

\author{
Raden Sudarwo'), Anfas ${ }^{2)}$, Irfandi Buamonabot ${ }^{3)}$ \\ ${ }^{1,2}$ Universitas Terbuka, ${ }^{3}$ Politeknik Sains \& Teknologi Wiratama Maluku Utara \\ Email: sudarwo@ut.ac.id
}

(Diterima: 07 September 2018; direvisi: 30 September 2018; dipublikasikan: 31 Oktober 2018 )

\begin{abstract}
Abstrak: Tujuan penelitian ini adalah untuk mengetahui dan menguji pengaruh kepuasan informasi terhadap kepuasan memilih perguruan tinggi. Responden dalam penelitian ini adalah mahasiswa Unit Program Belajar Jarak Jauh (UPBJJ) Universitas Terbuka Ternate. Sebanyak 74 responden dikumpulkan dari survei. Analisis data dilakukan dengan menggunakan regresi sederhana. Hasil penelitian menunjukkan bahwa kepuasan informasi berpengaruh positif terhadap kepuasan memilih perguruan tinggi.
\end{abstract}

Kata Kunci: Kepuasan; Kepuasan Informasi; Perguruan Tinggi.

\begin{abstract}
The purpose of this study is to determine and examine the effect of information satisfaction on choosing a college. Respondents in this study were students of the Ternate Open University Distance Learning Unit Program. A total of 74 respondents from the survey. Data analysis is done using simple regression. The results showed that information satisfaction had a positive effect on the satisfaction of choosing a college.
\end{abstract}

Key Word: Satisfaction; Information Satisfaction; College.

\section{PENDAHULUAN}

Salah satu tingkat pendidikan yang harus ditempuh seseorang sebelum bekerja adalah pendidikan tinggi. Menurut Undang-Undang Nomor 20 tahun 2012, Pendidikan Tinggi adalah jenjang pendidikan setelah pendidikan menengah yang mencakup program diploma, program sarjana, program magister, program doktor, dan program profesi, serta program spesialis, yang diselenggarakan oleh perguruan tinggi berdasarkan kebudayaan bangsa Indonesia. Dewasa ini, dunia kerja menuntut seseorang untuk menempuh pendidikan tinggi, sehingga akan mempermudah baik itu perusahaan maupun instansi pemerintahan untuk mempekerjakan mereka. Seseorang yang telah selesai menempuh pendidikan tinggi dianggap telah memiliki kompetensi yang memadai pada bidang keilmuannya.

Selain tuntutan dunia kerja bagi pelamar kerja, perguruan tinggi sebagai penyelenggara pendidikan tinggi baik program diploma, program sarjana, program magister, program doktor, dan program profesi, serta program spesialis juga dituntut untuk menyelenggarakan pendidikan yang bermutu. Mutu pendidikan pada perguruan tinggi dilihat dari seberapa baik penyajian Sistem Penjaminan Mutu Internal (SPMI) pada tingkat institusi dan program studi. Semakin baik SPMI pada tingkat institusi dan program studi maka akan berdampak pada hasil Sistem Penjaminan Mutu Eksternal (SPME) yang baik juga (Permenristek No. 62 tahun 2016). Luaran dari SPME adalah akreditasi yang merupakan bagian dari sistem nasional 
pendidikan tinggi. Akreditasi merupakan kegiatan penilaian untuk menentukan kelayakan program studi dan perguruan tinggi (Permenristek No. 32 tahun 2016). Luaran proses akreditasi dinyatakan dengan status akreditasi dan tidak terakreditasi. Data BAN PT tahun 2016 menunjukkan bahwa akreditasi program studi wilayah jawa dan luar jawa berdasarkan status akreditasi A, B dan C menunjukkan perbedaan yang cukup besar. Begitu juga pada status sudah dan belum terakreditasi. Tabel akreditasi program studi ditunjukkan pada tabel 1 .

Tabel 1 Akreditasi Program Studi

\begin{tabular}{|c|c|c|c|c|c|c|c|}
\hline \multirow{2}{*}{\multicolumn{2}{|c|}{ Wilayah }} & \multicolumn{3}{|c|}{ Prodi Terakreditasi } & \multirow{2}{*}{$\begin{array}{c}\text { Prodi } \\
\text { Terakreditasi }\end{array}$} & \multirow{2}{*}{$\begin{array}{l}\text { Prodi Belum } \\
\text { Terakreditasi }\end{array}$} & \multirow{2}{*}{$\begin{array}{l}\text { Total } \\
(5+6)\end{array}$} \\
\hline & & $\mathbf{A}$ & $\mathbf{B}$ & $\mathbf{C}$ & & & \\
\hline & 1 & 2 & 3 & 4 & 5 & 6 & 7 \\
\hline$*$ & Jawa & 1,805 & 4,463 & 3,003 & 9,271 & 2,139 & 11,410 \\
\hline$*$ & Luar Jawa & 359 & 3,555 & 3,929 & 7,843 & 5,385 & 13,228 \\
\hline$* *$ & Maluku Utara & 1 & 74 & 67 & 141 & - & - \\
\hline & $\begin{array}{c}\text { Universitas Terbuka } \\
\text { UPBJJ-UT Ternate }\end{array}$ & 5 & 29 & 3 & 37 & - & - \\
\hline & Total & 2,164 & 8,018 & 6,932 & 17,114 & 7,524 & 24,638 \\
\hline
\end{tabular}

Status prodi belum terakreditasi dan terakreditasi C pada tabel 1 di atas pada wilayah luar jawa cukup besar. Lebih spesifik lagi khususnya wilayah Maluku Utara hanya ada satu pun program studi pada perguruan tinggi terakreditasi A, sehingga berdasarkan data di atas, maka setiap pengambilan keputusan bagi calon mahasiswa yang akan memilih pemilihan perguruan tinggi harus benar-benar selektif. Keputusan yang selektif mempertimbangkan atribut perguruan tinggi yang bermutu sehingga akan berdampak pada kepuasan mahasiswa itu sendiri. Seperti yang diketahui ada 23 perguruan tinggi di Maluku Utara.

Keputusan masuk perguruan tinggi bukan hal yang mudah. Maraknya pemalsuan ijazah yang dilakukan oleh sejumlah perguruan tinggi "nakal" berakibat pada tidak terdaftarnya ijazah seseorang pada pangkalan data perguruan tinggi (Kompas, 2017 dan Surat Edaran Direktur Jenderal Belmawa Nomor 700/B/SE/2017 tentang Penggunaan Penomoran Ijazah Nasional (PIN) dan Sistem Verifikasi Ijazah Secara Elektronik (SIVIL)). Seseorang yang memilih perguruan tinggi akan sangat berhati-hati, sehingga tiap perguruan tinggi akan menawarkan sejumlah atributnya ( biaya pendidikan, lokasi, promosi, program akademik, fasilitas pendidikan, reputasi perguruan tinggi dan ketersediaan bantuan

keuangan) dan teknologi informasi seperti website yang terbaik baik para calon pemilih (Ismail, 2008; Ismail dan Louw, 2008; Ismail, 2009; dan Ismail, Faridah dan Nooraini, 2010).

Model yang diajukan oleh Ismail (2009) mengemukakan bahwa atribut yang bermutu tentu harus diinformasikan kepada pengguna perguruan tinggi. Pengguna yang mendapatkan kepuasan informasi yang akurat tentu akan merasa puas telah memilih Perguruan Tinggi tersebut.

Penelitian ini dilaksanakan Universitas Terbuka. Seperti yang diketahui Universitas Terbuka merupakan perguruan tinggi yang terdaftar pada wilayah DKI Jakarta (BAN PT, 2018) dan mempunyai unit kerjanya tersebar di seluruh Indonesia, salah satunya di Provinsi Maluku Utara. Universitas Terbuka sebagai perguruan tinggi yang diakui menerapkan pembelajaran jarak jauh oleh pemerintah memiliki proses pembelajaran yang berbeda dengan perguruan tinggi lain di Maluku Utara. Universitas Terbuka pada proses pembelajarannya dengan jumlah tatap muka 8 (delapan) kali, 3 (tiga) kali penugasan bagi mahasiswa dan belajar mandiri, sedangkan Perguruan Tinggi lain menerapkan jumlah tatap muka 16 (enam belas) kali dan 4-6 kali penugasan. Selain itu, setiap tahun jumlah mahasiswa pada UPBJJ UT Ternate mengalami kenaikan, tetapi setelah satu tahun pertama perkuliahan berjalan jumlah tersebut mengalami penurunan (UPBJJ-UT Ternate, 2018). Tujuan penelitian adalah menguji pengaruh kepuasan informasi terhadap kepuasan memilih perguruan tinggi.

Berdasarkan hasil pemaparan di atas, penelitian ini menggunakan model yang dikembangkan oleh Ismail (2009). Sepengetahuan peneliti, penelitian terkait kepuasan informasi terhadap kepuasan 
memilih mahasiswa masih sangat jarang diteliti di Indonesia, sehingga peneliti ingin melakukan penelitian dengan judul Pengaruh Kepuasan Informasi terhadap Kepuasan Memilih Mahasiswa (Studi pada Universitas Terbuka).

\section{Tinjauan Pustaka}

Kepuasan adalah tanggapan pelanggan atas terpenuhinya kebutuhannya. Hal itu berarti menilai bahwa suatu bentuk keistimewaan dari suatu barang atau jasa atau barang/jasa itu sendiri, memberikan tingkat kenyamanan yang terkait dengan pemenuhan suatu kebutuhan termasuk pemenuhan kebutuhan di bawah harapan atau pemenuhan kebutuhan melebihi harapan (Oliver, 1997). Untuk memuaskan para pelanggan, kita perlu memahami apa yang penting bagi mereka dan berusaha memenuhi harapan-harapan mendasar pelanggan. Kebutuhan pelanggan tidak hanya mengenai barang dan jasa itu sendiri, banyak faktor yang mempengaruhi kepuasan pelanggan.

Kotler dan Keller (2016) mendefinisikan kepuasan sebagai perasaan senang ataukecewa seseorang yang muncul setelah membandingkan antara persepsi/ kesannya terhadap kinerja suatu produk dan harapanharapannya. Menurut definisi tersebut, kepuasan merupakan fungsi dari persepsi/ kesan atas kinerja dan harapan. Jika kinerja beradadi bawah harapan maka pelanggan tidak puas. Sebaliknya, jika kinerja melebihi harapan maka pelanggan merasa puas. Kepuasan dan ketidakpuasan konsumen sangat dipengaruhi oleh pengalaman mengkonsumsi produk atau jasa sebelumnya (Oliver, 1993). Banyak perusahaan memfokuskan pada kepuasan pelanggan karena pelanggan yang puas tidak mudah pilihannya. Kepuasan pelanggan yang tinggi menciptakan keeratan emosional terhadap merek tertentu, bukan hanya kesukaan/preferensi rasional. Sebagai hasilnya adalah kesetiaan (loyalitas) pelanggan yangtinggi.

Kepuasan informasi didefinisikan sebagai kesepakatan individu atas kepuasan informasi yang digunakan dalam memilih layanan. Informasi yang dikumpulkan mengenai masing-masing perguruan tinggi akan menjadi dasar evaluasi utama siswa dalam mengejar pemilihan perguruan tinggi untuk dipelajari. Umumnya siswa akan mencari dan mengevaluasi informasi dari sampai lima perguruan tinggi dalam proses penentuan pilihan perguruan tinggi mereka (Ismail dan Leow, 2008). Dalam penelitian mereka, juga disarankan agar dalam proses pencarian siswa, sumber informasi yang didominasi pasar (bahan cetak dan situs perguruan tinggi) lebih banyak digunakan dibandingkan dengan sumber informasi pribadi (misalnya anggota keluarga dan teman). Oleh karena itu, sangat penting bagi institusi pendidikan untuk memastikan bahwa siswa merasa puas dengan informasi yang mereka dapatkan selama tahap awal proses pengambilan keputusan ini karena perasaan puas dapat menyebabkan perilaku pilihan.

\section{Hipotesis Penelitian}

Isu penting yang menjadi perhatian penyedia layanan adalah memahami proses layanan evaluasi pelanggan. Selain kepuasan pasca pembelian, juga relevan untuk mengetahui bahwa kepuasan terhadap informasi juga dapat terjadi sebelum pilihan dibuat. Selama tahap awal proses pengambilan keputusan, pelanggan akan mengevaluasi layanan potensial melalui informasi yang diperoleh, harapan bahwa pelanggan terkait dengan layanan akan sangat bergantung pada informasi yang dikumpulkan dari pilihan sumber. Dalam proses memilih perguruan tinggi, sangat penting bagi siswa untuk memperoleh semua informasi yang dibutuhkan dari berbagai sumber karena mereka dapat membuat penilaian yang lebih baik dan merasa puas dengan pilihan kuliah mereka. Sangat logis bahwa sebelum seorang siswa dapat puas dengan pilihannya, dia harus terlebih dahulu merasa puas dengan informasi yang diperoleh mengenai perguruan tinggi tersebut. Oleh karena itu kepuasan informasi sangat penting karena merupakan keharusan dalam penilaian kinerja perguruan tinggi (Ismail, 2008, Ismail dan Louw, 2008; Ismail, 2009; dan Ismail, Faridah dan Nooraini, 2010).

Hipotesis: Kepuasan Informasi berpengaruh terhadap kepuasan memilih perguruan tinggi.

\section{METODE PENELITIAN}

Penelitian ini dilakukan Unit Program Belajar Jarak Jauh Universitas Terbuka Ternate. Data yang digunakan pada penelitian ini dikumpulkan dengan metode survei yang menggunakan kuesioner. Survei merupakan metode yang tepat untuk pertanyaan penelitian mengenai kepercayaan dan mengurangi tingkat 
kesalahan pada metode kualitatif (Cooper dan Schindler, 2014).

\section{Populasi dan Sampel}

Populasi dalam penelitian ini adalah seluruh mahasiswa Unit Belajar Jarak Jauh Universitas Terbuka Ternate. Ukuran sampel yang digunakan pada penelitian ini sebanyak 74 responden. Sampel yang digunakan pada penelitian ini akan diambil dengan metode non probability sampling yaitu purposive sampling dengan pendekatan judgment sampling yaitu melibatkan pemilihan subjek yang berada ditempat yang paling menguntungkan atau dalam posisi terbaik untuk memberikan informasi yang diperlukan (Sekaran dan Bougie, 2016). Purposive sampling dipilih berdasarkan pertimbangan bahwa mahasiswa yang menjadi sampel adalah mahasiswa yang sudah melakukan registrasi.

\section{Definisi Operasional dan Penyusunan Variabel \\ Variabel yang digunakan dalam penelitian ini adalah kepuasan memilih perguruan tinggi dan kepuasan informasi. Masing-masing variabel tersebut mempunyai definisi operasional sebagai berikut:}

\section{a.Kepuasan Memilih Perguruan Tinggi}

Kepuasan adalah tanggapan pelanggan atas terpenuhinya kebutuhannya. Hal itu berarti menilai bahwa suatu bentuk keistimewaan dari suatu barang atau jasa atau barang/jasa itu sendiri, memberikan tingkat kenyamanan yang terkait dengan pemenuhan suatu kebutuhan termasuk pemenuhan kebutuhan di bawah harapan atau pemenuhan kebutuhan melebihi harapan (Oliver, 1997). Variabel keputusan memilih perguruan tinggi diukur dengan menggunakan skala likert 1-5.
Kepuasan informasi didefinisikan sebagai kesepakatan individu atas kepuasan informasi yang digunakan dalam memilih layanan (Ismail, 2008). Variabel Kepuasan Informasi diukur dengan menggunakan skala likert 1-5.

\section{Pengujian Instrumen Penelitian}

Validitas merupakan tingkat di mana sebuah pengujian mengukur apa yang benarbenar ingin diukur. Pengujian validitas dilakukan dengan faktor analisis untuk mendapatkan constructvalidity. Item yang digunakan dalam penelitian adalah yang mempunyai nilai factor loading $\geq 0,5$ (Hair et al., 2010).

Reliabilitas berkaitan dengan akurasi dan presisi dari sebuah prosedur pengukuran (Cooper dan Schidler, 2014). Pada penelitian ini, uji reliabilitas dilakukan dengan melihat nilai Cronbach's Alpha yaitu diatas 0,6 (Hair et al., 2010).

\section{Analisis Data dan Pengujian Hipotesis}

Pengujian hipotesis dalam penelitian ini menggunakan regresi sederhana. Ketepatan fungsi regresi dalam menaksir nilai aktual dapat diukur dari goodness of fit-nya. Secara statistik setidaknya dapat diukur dari nilai statistik t, dan koefisien determinasinya (Hair et al. 2010).

\section{PEMBAHASAN}

Responden pada penelitian ini adalah mahasiswa UPBJJ-UT Ternate yang tersebar disejumlah pokjar. Proses penyebaran sebanyak 85 kuesioner. Dari 81 (95\%) kuesioner yang dikembalikan, hanya 74 (87\%) kuesioner yang dinyatakan memenuhi syarat untuk dianalisis dalam rangka pengujian hipotesis.

\section{b.Kepuasan Informasi}

Tabel 2 Hasil Penyebaran Kuesioner

\begin{tabular}{lcc}
\hline \multicolumn{1}{c}{ Keterangan } & Jumlah & Persentase \\
\hline Kuesioner yang disebar & 85 & $100 \%$ \\
\hline Kuesioner yang tidak kembali & 4 & $4 \%$ \\
\hline Kuesioner yang kembali & 81 & $96 \%$ \\
\hline Kuesioner yang tidak dapat diolah & 7 & $6 \%$ \\
\hline Kuesioner yang dapat diolah & 74 & $90 \%$ \\
\hline
\end{tabular}

Sumber: data diolah, 2018 

Dengan demikian tingkat respon dalam penelitian adalah $87 \%$. Hasil penyebaran kuesioner ditunjukkan pada tabel 2. Selanjutnya responden dalam penelitian ini terdiri dari 40 orang laki-laki (54\%) dan 34 (46\%). Tabel 3 menunjukkan karakteristik responden berdasarkan gender.

Tabel 3 Karakteristik Responden berdasarkan Gender

\begin{tabular}{lccc}
\hline & Gender & Jumlah & Persentase \\
\hline Laki & 40 & $54 \%$ \\
\hline Perempuan & 34 & $46 \%$ \\
\hline Total & $\mathbf{7 4}$ & $\mathbf{9 6 \%}$ \\
\hline
\end{tabular}

Sumber: data diolah, 2018

Hasil pengujian validitas menunjukkan bahwa baik pada item pertanyaan variabel kepuasan informasi dan kepuasan memilih perguruan tinggi sudah berada di atas loading factor yakni lebih besar dari 0,5 . Selanjutnya untuk hasil pengujian reliabilitas baik pada pada item pertanyaan variabel kepuasan informasi dan kepuasan memilih perguruan tinggi juga sudah reliabel dengan nilai cronbach's alpha ratarata di atas 0,6. Hasil uji validitas dan reliabilitas kepuasan informasi dan kepuasan memilih perguruan tinggi ditunjukkan pada tabel 4

Tabel 4 Hasil Uji Validitas dan Reliabilitas Kepuasan Informasi dan Kepuasan Memilih Perguruan Tinggi

\begin{tabular}{|c|c|c|c|}
\hline Item Pertanyaan & Komponen 1 & Croanbach's alpha & Keterangan \\
\hline Kepuasan Informasi 1 & 0,866 & \multirow{2}{*}{0,663} & Valid dan Reliabel \\
\hline Kepuasan Informasi 2 & 0,866 & & Valid dan Reliabel \\
\hline Kepuasan Memilih Perguruan Tinggi 1 & 0,687 & \multirow{5}{*}{0,814} & Valid dan Reliabel \\
\hline Kepuasan Memilih Perguruan Tinggi 2 & 0,735 & & Valid dan Reliabel \\
\hline Kepuasan Memilih Perguruan Tinggi 3 & 0,850 & & Valid dan Reliabel \\
\hline Kepuasan Memilih Perguruan Tinggi 4 & 0,790 & & Valid dan Reliabel \\
\hline Kepuasan Memilih Perguruan Tinggi 5 & 0,725 & & Valid dan Reliabel \\
\hline
\end{tabular}

Sumber: data diolah, 2018

\section{Pengujian Hipotesis}

Hipotesis menyatakan bahwa terdapat pengaruh kepuasan informasi pada kepuasan memilih perguruan tinggi. Seperti disajikan pada tabel 5, hasil analisis regresi menunjukkan bahwa, kepuasan informasi berpengaruh positif signifikan $(\beta=0,301, \mathrm{t}$ $=2,759, \mathrm{P}<0,05)$. Ini berarti hipotesis yang menyatakan bahwa kepuasan informasi berpengaruh pada kepuasan memilih perguruan tinggi, didukung.

Tabel 5 Hasil Pengujian Hipotesis Menggunakan Regresi

\begin{tabular}{lccc}
\hline \multirow{2}{*}{ Variabel independen } & \multicolumn{4}{c}{ Kepuasan Memilih Perguruan Tinggi } \\
\cline { 2 - 4 } & $\boldsymbol{\beta}$ & $\mathbf{T}$ & Sig \\
\hline Kepuasan Informasi & 0,301 & 2,759 & 0,007 \\
\hline Sumber: data diolah, 2018 & & &
\end{tabular}

\section{Pembahasan Hipotesis}

Hasil penelitian menunjukkan bahwa kepuasan informasi berpengaruh terhadap kepuasan memilih perguruan tinggi. Hasil penelitian ini juga konsisten dengan pendapat Kotler dan Keller (2016) yang mendefinisikan kepuasan sebagai perasaan senang ataukecewa seseorang yang muncul setelah membandingkan antara persepsi/ kesannya terhadap kinerja suatu produk dan harapanharapannya.Menurutdefinisitersebut,kepuasan merupakan fungsi dari persepsi/kesan atas kinerja dan harapan. Jika kinerja beradadi bawah harapan maka pelanggan tidak puas. Sebaliknya, jika kinerja melebihi harapan maka pelanggan merasa puas. Hasil penelitian 
ini juga konsisten dengan penelitian Ismail (2009).

\section{SIMPULAN DAN SARAN}

\section{Simpulan}

Berdasarkan hasil dan pembahasan pada penelitian ini maka dapat diambil kesimpulan sebagai berikut kepuasan informasi berpengaruh berpengaruh terhadap kepuasan memilih perguruan tinggi.

\section{Saran}

Beberapa saran yang dapat diajukan peneliti untuk dilakukan pada penelitian mendatang adalah:

a.Penelitian ini menggunakan sampel yang homogeny, akan lebih baik penelitian mendatang menggunakan sampel yang heterogen untuk mendapatkan variasi yang lebih besar. Selain itu, penggunaan sampel yang heterogen akan memberikan informasi yang lebih general.

b.Penelitian ini menggunakan teknik non probability sampling yaitu porpusive sampling dengan pendekatan judgment sampling akan lebih baik jika pada penelitian selanjutnya menggunakan jumlah sampel yang lebih banyak sehingga bisa digeneralisasi.

Penelitian ini terbatas pada sampel dan setting mahasiswa Universitas Terbuka, untuk itu pada penelitian yang akan datang generalisasi pada subyek yang berbeda harus lebih diperhatikan, sehingga penelitian yang akan datang secara eksternal valid pada setting yang berbeda. 


\section{DAFTAR PUSTAKA}

ban.pt.or.id

Cooper, D. R., \& Schlinder. P. S. 2014. Bussiness Research Methods, 12th edition. Mc Graw. New York.

Hair, J. F. Jr., William, C. B., Banin, B. J., \& Anderson, R. E. 2010. Multivariate Data Analysis. $7^{\text {th }}$ edition. Upper Saddle River- Prentice Hall. New Jersey.

Ismail, N. 2008. International students' satisfaction in their choice of a private higher education institution, paper presented at the 9th International Business Research Conference, 24 November - 26 November, Melbourne, Australia.

Ismail, N. 2009. Mediating effect of information satisfaction on college choice. Paper presented in Oxford Business \& Economics Conference Program. UK.

Ismail, N., \& Leow, Y. M. 2008. Sourcing for Information: A Private Higher Education Perspective, paper presented at the 9th International Business Research Conference, 24-26

November, Melbourne, Australia.

Ismail, N., Nooraini, M. S., \& Noorzaidi., M. D. 2010. Determining Mediating Effect of Information Satisfaction on International Students' College Choice: Empirical Evidence in Malaysia's University. International Journal of Scientific Research in Education, Vol. 3(1), 51-63

kompas.com
Kotler, P., \& Keller, K. L. 2016. Marketing Management 15 e. Global Edition. Pearson

Oliver, R. L. 1997., Satisfaction A Behavioral Perspective On The Consumer. McGraw-Hill Education, Singapore.

Oliver, R. L. 1993. "Cognitive, Affective, and Atribute Bases forthe Satisfaction Response," Journal of Consumer Research, Vol.20, December, pp.418430.

Sekaran, U., \& Bougie, R. 2016. Research Methods for Business: A Skill-Building Approach. $7^{\text {th }}$ edition. Chichester, West Sussex, United Kingdom: John Wiley \& Sons

Peraturan Menteri Riset, Teknologi, Dan Pendidikan Tinggi Republik Indonesia Nomor 32 Tahun 2016 Tentang Akreditasi Program Studi Dan Perguruan Tinggi

Peraturan Menteri Riset, Teknologi, Dan Pendidikan Tinggi Republik Indonesia Nomor 62 Tahun 2016 Tentang Sistem Penjaminan Mutu Pendidikan Tinggi

Surat Edaran Direktur Jenderal Belmawa Nomor 700/B/SE/2017 tentang Penggunaan Penomoran Ijazah Nasional (PIN) dan Sistem Verifikasi Ijazah Secara Elektronik (SIVIL)

Undang Undang Nomor 20 Tahun 2012 Tentang Pendidikan Tinggi. 